\title{
Feasibility study for epidemic prevention and control in a regional hospital
}

\author{
YUNG-LIANG CHEN ${ }^{1}$, MING-YANG YEH ${ }^{2}$, SHAU-YEN HUANG ${ }^{6}$, CHI-MING LIU ${ }^{3}$, CHI-CHEN SUN $^{4}$, \\ HSU-FENG LU ${ }^{1,5,6}$, TSAN-HUNG CHIU ${ }^{7}$, TE-CHUN HSIA ${ }^{8,9}$ and JING-GUNG CHUNG ${ }^{10,11}$ \\ ${ }^{1}$ Department of Medical Laboratory Science and Biotechnology, Yuanpei University, Hsinchu 300; \\ ${ }^{2}$ Office of the Director; Departments of ${ }^{3}$ Research and Education, ${ }^{4}$ Nursing, and ${ }^{5}$ Clinical Pathology, \\ Cheng-Hsin General Hospital, Taipei 112; ${ }^{6}$ Department of Restaurant, Hotel and Institutional Management, \\ Fu-Jen Catholic University, New Taipei 242; Departments of ${ }^{7}$ Obstetrics and Gynecology, and ${ }^{8}$ Internal Medicine, \\ China Medical University Hospital, Taichung 404; ${ }^{9}$ Graduate Institute of Integrated Medicine, China \\ Medical University, Taichung 404; ${ }^{10}$ Department of Biotechnology, Asia University, Taichung 413; \\ ${ }^{11}$ Department of Biological Science and Technology, Taichung 404, Taiwan, R.O.C.
}

Received September 15, 2011; Accepted December 20, 2011

DOI: $10.3892 / \mathrm{mmr} .2011 .730$

\begin{abstract}
Epidemic prevention policies in hospitals address issues such as, indoor air quality control, cleanliness of medical staff clothing and employee hand-washing procedures. Our hospital employed Bio-Kil to treat air-conditioning filters and nursing staff uniforms. We also assessed the efficacy of different detergents. Using Bio-Kil technology, the mean bacterial count in the air was reduced from $108.8 \mathrm{CFU} / \mathrm{h} /$ plate $(n=420)$ to $68.6 \mathrm{CFU} / \mathrm{h} /$ plate $(\mathrm{n}=630)$. On the lower hems of the Bio-Kil-treated gowns, the mean bacterial count was $1,201 \mathrm{CFU} / 100 \mathrm{~cm}^{2}$, markedly lower than the bacterial count of $7,753 \mathrm{CFU} / 100 \mathrm{~cm}^{2}$, found on the parts of the gowns not treated with Bio-Kil ( $\mathrm{p}=0.0401)$. On the cuffs of sleeves treated with Bio-Kil, the mean count was $1,165 \mathrm{CFU} / 100 \mathrm{~cm}^{2}$, markedly lower than that of 2,131 CFU/100 $\mathrm{cm}^{2}$, found on the cuffs not treated with Bio-Kil ( $\mathrm{p}=0.0073)$. With regard to the mean bacterial eradication rates of antimicrobial solutions, Steridal Solution, 75\% alcohol and Bio-Kil (3rd generation) were shown to be the most effective, with rates exceeding $80 \%$. Hibiscrub with paper towels and Fresh Protect Skin were the second most effective. Bio-Kil (1st generation), tap water with paper towels, liquid hand soap with paper towels and ozone water were the least effective. One important observation was that hand-washing without the use of paper towels increased the bacterial count by as much as $84 \%$. Bio-Kil is effective in
\end{abstract}

Correspondence to: Dr Jing-Gung Chung, Department of Biological Science and Technology, China Medical University, No. 91 Hsueh-Shih Road, Taichung 404, Taiwan, R.O.C.

E-mail: jgchung@mail.cmu.edu.tw

Dr Hsu-Feng Lu, Department of Clinical Pathology, Cheng-Hsin General Hospital, No. 45 Cheng Hsin St., Taipei 112, Taiwan, R.O.C. E-mail: ch1835@chgh.org.tw

Key words: air quality control, Bio-Kil, ozone water reducing bacterial counts in the air, on nursing staff uniforms and is an effective detergent.

\section{Introduction}

Healthcare-associated infections in hospitals pose a significant economic burden on the nation's healthcare system (1). The Center of Disease Control (CDC) estimates that approximately 2 million nosocomial infections occur every year, and approximately 90,000 patients die as a result (2). The incidence of health-care-associated infections can be minimized by the i) appropriate use of cleaners and disinfectants; ii) appropriate maintenance of medical equipment (e.g., automated endoscope reprocessors or hydrotherapy equipment); iii) adherence to water-quality standards for hemodialysis and ventilation standards for specialized care environments (e.g., airborne infection isolation rooms, protective environments or operating rooms) (3).

Air quality evaluation includes measuring the levels of carbon monoxide and carbon dioxide, the temperature, the relative humidity and the airborne bacterial counts. Of all the factors measured, airborne bacterial count poses the highest risk of infection and is the prime target for prevention of nosocomial infections. The Taiwanese government recently reported that the air quality in the major hospitals in Taipei require improvement.

Apart from the air quality, the medical staff gowns may be the source of nosocomial infections. A survey conducted by the Institute of Occupational Safety and Health in the Council of Labor Affairs in Taiwan claimed that doctors' white coats are highly unclean. Doctors, however, are the least likely to wash their work clothing. Convincing the doctors to do bacterial cultures on their clothing was quite difficult, therefore, specimens were obtained from the uniforms of the nursing staff.

In 1988 and 1995, guidelines for hand-washing and antisepsis were published by the Association for Professionals in 
Infection Control (APIC; 4,5). The recommended indications for hand-washing were similar to those listed in the CDC guidelines. The 1995 APIC guidelines included a more detailed discussion of alcohol-based hand rubs and supported their use in more clinical settings than had been recommended in earlier guidelines. In 1995 and 1996, the Healthcare Infection Control Practices Advisory Committee (HICPAC) recommended that either antimicrobial soap or a waterless antiseptic agent be used for cleaning hands upon leaving the rooms of patients with multidrug-resistant pathogens [e.g., vancomycin-resistant enterococci (VRE) and methicillin-resistant Staphylococcus aureus (MRSA)] $(6,7)$. These guidelines also provided instructions for hand-washing and antisepsis in other clinical settings, including routine patient care. Although the APIC and HICPAC guidelines have been adopted by the majority of hospitals, adherence of health-care workers to recommended hand-washing practices has remained low $(8,9)$. A study at the Royal Children's Hospital in Australia showed that only 50-95\% of doctors followed hand-washing rules, and only $9 \%$ followed standard protocols for hand-washing (10). These low rates may be attributed to the fact that hand-washing is time-consuming, causes dry skin and because hand-washing equipment is not always easily accessible; furthermore, the hand-washing procedure interrupts continuous operations. As a result, time-saving products are currently being developed that do not require water, are portable and reduce the adverse effects of skin dryness. Such products may be alcoholbased and antimicrobial hand sanitizers, including Bio-Kil and other similar products. In 2002, addressing the issue of handwashing and new possible solutions, the World CDC revised the guidelines for medical and hygienic hand-washing, pointing out that the use of alcohol sanitizers improves hand-washing compliance and reduces the transmission of diseases (11-13). However, there are currently no published reports of domestic investigations regarding hand-washing methods and product comparisons to serve as a reference. Additionally, it must be determined whether the bactericidal efficacy of alcohol-based sanitizers and Bio-Kil sanitizers could effectively replace traditional hand-washing.

Our study aimed to demonstrate the need for new solutions and to propose potential ones. We surveyed the indoor air quality in a regional hospital and studied ways of improving it. We also performed bacterial cultures for the most common sanitizers in the market, in order to compare the bactericidal effects of all types of dry and wet sanitizers.

\section{Materials and methods}

Reduction of airborne bacteria prior to and following treatment with Bio-Kil. To collect airborne bacteria samples, the tryptic soy agar (TSA; Difco, Franklin Lakes, NJ, USA) plates were placed in seven sites and left open for $60 \mathrm{~min}$ (Fig. 1). These sites were A, B, L (the waiting areas of Clinics 35-40, including the waiting areas of the Departments of Neurology, Cardiology and Chest medicine), D (the waiting area of Clinics 1-20), F (the aisle of the clinics of Chest Medicine and Orthopedics), K (the hall) and $\mathrm{M}$ (the service counter of the nursing station in the clinics). The sampling time was 10:30 to 11:30 in the morning and 1:30 to 2:30 in the afternoon, when the patient load was at its peak, 5 days a week, excluding the weekend.
The untreated hospital filters were used as controls and were left unchanged for 6 weeks. The air conditioner filters treated with Bio-Kil (Cargico Group Corp., Taiwan) were used as the experimental group and were left unchanged for 9 weeks. Thereafter, samples were incubated for $48 \mathrm{~h}$ at $35^{\circ} \mathrm{C}$ with $5 \% \mathrm{CO}_{2}$.

Bactericidal study of Bio-Kil for the treatment of nursing staff uniforms. Since the process of sampling may affect the work morale, only two wards were included in the experiment, Ward 61 and Ward 62, where the patient turnover rate was lower. Each participant was asked to record the number of days the clothes had been worn (including the dates the clothes were first and last worn), and the number of patients cared for. Each participant recorded these items in detail. The 29 staff nurses were separated into two groups: Group 1 had 14 nurses who each had an $11 \times 11 \mathrm{~cm}^{2}$ patch of sterile fabric on the left lower hem as a control and another patch treated with Bio-Kil on the right lower hem as the experimental sample. In addition, an $11 \times 11 \mathrm{~cm}^{2}$ patch of sterile fabric was placed on the cuff of each nurse's left sleeve as a control and another patch treated with Bio-Kil was placed on the cuff of the right sleeve as the experimental sample. The remaining 15 of the 29 staff nurses each had an $11 \times 11 \mathrm{~cm}^{2}$ patch of fabric on the right lower hem and cuff of the right sleeve as controls, and another treated patch of the same size on the left lower hem and cuff of the left sleeve as experimental samples. These patches were later removed.

Vials containing $100 \mathrm{ml}$ normal saline were autoclaved at $121^{\circ} \mathrm{C}$ for $15 \mathrm{~min}$ and subsequently placed in the sterile hood. Vials containing $8 \mathrm{~g}$ TSA in $200 \mathrm{ml} \mathrm{H}_{2} \mathrm{O}$ were autoclaved at $121^{\circ} \mathrm{C}$ for $15 \mathrm{~min}$, then put into the $45-46^{\circ} \mathrm{C}$ water bath until further use. The experimental samples were added to the vials containing $100 \mathrm{ml}$ sterile normal saline and the vials were vortexed five times for $5 \mathrm{sec}$ each time. The culture medium was removed from the water bath, poured onto each plate and left to cool at room temperature. Rinsed samples $(1 \mathrm{ml})$ were taken from each vial and inoculated onto each plate, which was then incubated. The bacterial counts were obtained manually. The calculation of bacterial counts was carried out as follows: [(bacterial colonies x $\left.100 \mathrm{ml}) / 121 \mathrm{~cm}^{2}\right] \times 100 \mathrm{~cm}^{2}=$ actual CFU/100 $\left.\mathrm{cm}^{2}\right]$.

Comparison and confirmation of different types of handcleaning methods. To assess the differences between the number of bacterial colonies in the right and left palms of hands, 20 volunteer hospital staff members pressed their right and left palms, with neither palm washed or treated, onto the $150 \times 15 \mathrm{~mm}^{2}$ Mueller Hinton agar (M-H agar; Becton Dicknson, USA). The plates were incubated. Subsequently, the colonies were counted manually. Paired Student's t-test was applied, confirming no difference in the number of colonies between the left and right palms of the hands of the participants.

To assess the efficacy of different detergents, 200 volunteers were separated into 10 groups with 20 participants in each group. Groups 1 to 10 randomly pressed either their right or left palm onto the $\mathrm{M}-\mathrm{H}$ agar before washing their hands. The plates were incubated. Then, Group 1 to 10 separately washed their other hand with one of 10 hand-washing 


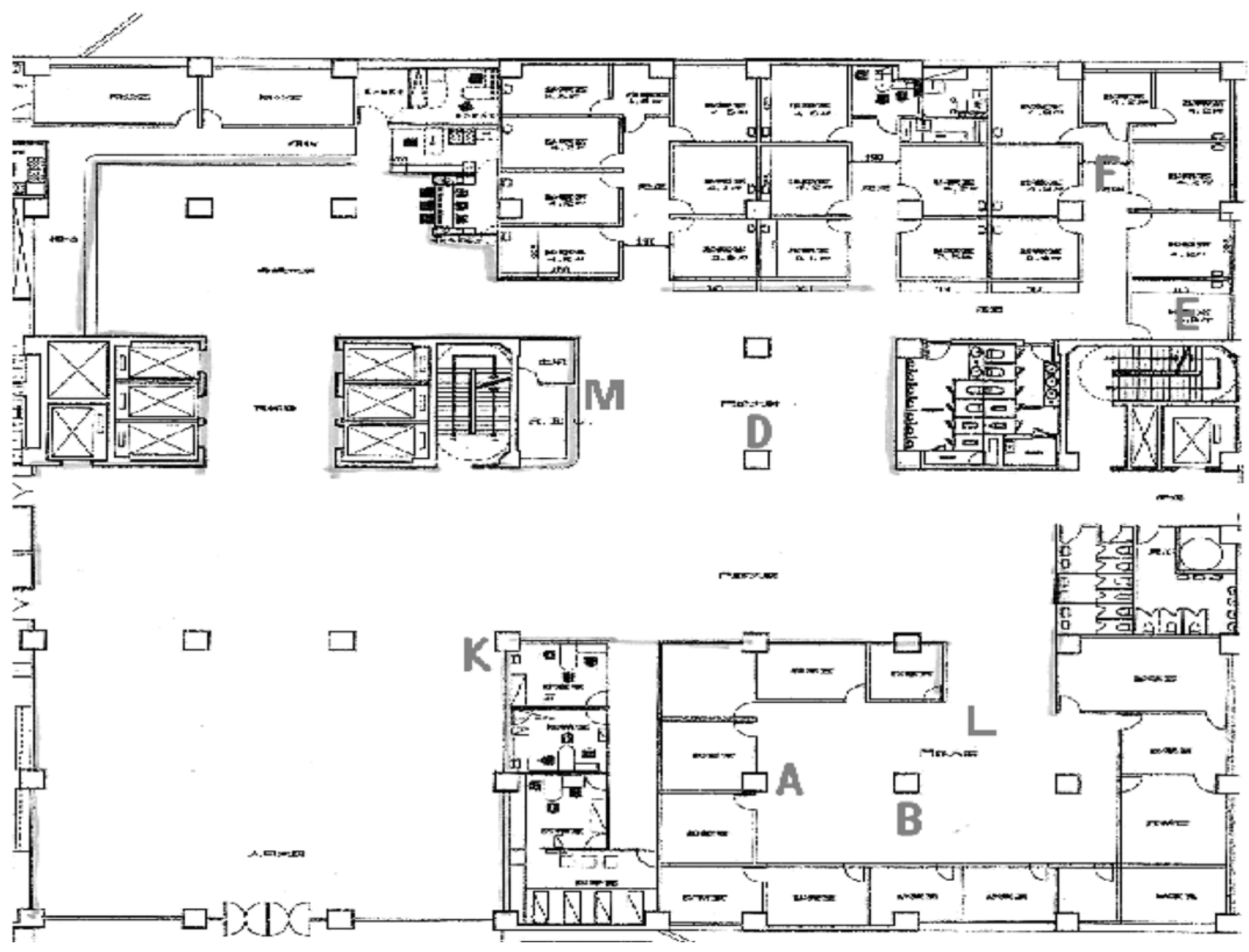

Figure 1. Map shows the 7 sites from where samples were obtained; the waiting areas of A, B, L (Departments of Neurology, Cardiology and Pulmonary Medicine), D (room no. 1-20), F (aisle between the Pulmonary Medicine and Orthopedics Department), K (lobby) and M (Outpatient Service Counter).

methods, including tap water with natural drying, tap water with paper towels, liquid soap (Dial Corp., USA) with paper towels, 75\% alcohol (Tien Chen Pharmaceutical Co., Taiwan), Hibiscrub (Peterlee Corp., UK) with paper towels, Bio-Kil (1st generation; Cargico Group Corp.), Steridal Solution (Shining Co. Ltd., Taiwan), Fresh Protect Skin Sanitizer (Omega Corp., USA), Bio-Kil (3rd generation; Cargico Group Corp.) and 'ozone natural dry' (O-three Corp., Taiwan). Bacterial cultures were then obtained from the other palm, which had not been pressed against the plate yet. The hand-cleaning methods followed the protocols (distinguished as dry washing and wet washing according to the purposes of the experiments) guided by the CDC in the Department of Health (http://www.cdc.gov. tw/ct.asp? $x$ Item $=13366 \&$ ctNode $=1888 \& \mathrm{mp}=1$ ). Finally, the differences between the number of bacterial colonies prior to and following washing were converted into the bacterial eradication rate. Bacterial eradication rates equaled the difference in the number of bacterial colonies before and after washing divided by the number of bacterial colonies before washing and multiplied by $100 \%$ [(no. of colonies before washing - no. of colonies after washing)/(no. of colonies before washing) $\mathrm{x}$ $100 \%]$. In the experiment, 40 values in total represented each group, including the bacterial colony counts on the plates before and after washing. The bacterial eradication rate was calculated separately and the mean eradication rate for each group was then estimated.

Data analysis and statistical methods. Comparison of bacterial counts of the air-conditioning system prior to and following the treatment of Bio-Kil was analyzed by the Student's t-test. Paired Student's t-test was used to analyze the presence of bacterial resistance after applying Bio-Kil on the lower hems and the comparisons of the number of bacterial colonies on the lower hems and the cuffs of sleeves on the uniforms of the same participants. The mean bacterial counts of the lower hems and cuffs of sleeves of the nursing staff on the first, second and third days were compared by one-way analysis of variance (ANOVA). The statistical package used was Microsoft Excel version 97 (Microsoft, USA).

\section{Results}

Reduction of airborne bacterial counts prior to and following treatment of the air-conditioning system with Bio-Kil. Prior to 
Table I. Mean airborne bacterial counts per day for one week, collected from 7 sites prior to and following treatment of the air-conditioning system with Bio-Kil.

\begin{tabular}{|c|c|c|c|c|c|c|c|c|}
\hline \multirow[b]{2}{*}{ Week } & \multicolumn{7}{|c|}{ Sites } & \multirow[b]{2}{*}{ Mean counts $(\mathrm{CFU} / \mathrm{h} /$ plate $)$} \\
\hline & A & $\mathrm{B}$ & $\mathrm{L}$ & $\mathrm{D}$ & $\mathrm{F}$ & $\mathrm{K}$ & M & \\
\hline 1 & 57.5 & 68.0 & 64.3 & 101.3 & 92.1 & 80.5 & 93.5 & 77.3 \\
\hline 2 & 68.4 & 57.5 & 67.4 & 129.9 & 116.4 & 137.7 & 112.1 & 96.2 \\
\hline 3 & 85.7 & 78.7 & 72.2 & 158.0 & 129.3 & 219.5 & 122.2 & 123.9 \\
\hline 4 & 82.8 & 72.8 & 67.3 & 235.0 & 125.0 & 229.2 & 152.7 & 135.4 \\
\hline 5 & 108.4 & 131.3 & 56.3 & 114.3 & 155.6 & 140.2 & 114.9 & 117.7 \\
\hline 6 & 83.7 & 131.8 & 70.8 & 140.7 & 130.9 & 156.8 & 138.5 & 119.1 \\
\hline Control group & 80.6 & 92.2 & 65.9 & 138.8 & 124.5 & 150.8 & 120.0 & 108.8 \\
\hline 7 & 51.6 & 67.3 & 46.4 & 129.8 & 89.1 & 99.6 & 124.7 & 80.6 \\
\hline 8 & 80.5 & 76.1 & 50.2 & 110.5 & 86.5 & 103.2 & 97.5 & 84.5 \\
\hline 9 & 61.4 & 64.2 & 44.4 & 102.6 & 86.8 & 94.6 & 84.1 & 75.7 \\
\hline 10 & 39.7 & 57.3 & 42.8 & 90.0 & 67.9 & 85.8 & 70.4 & 63.9 \\
\hline 11 & 43.6 & 59.2 & 40.8 & 85.6 & 88.7 & 65.7 & 78.2 & 63.9 \\
\hline 12 & 59.2 & 47.7 & 41.8 & 83.5 & 69.8 & 65.3 & 66.2 & 61.2 \\
\hline 13 & 43.6 & 55.6 & 61.9 & 95.9 & 74.8 & 82.1 & 94.5 & 69.0 \\
\hline 14 & 59.1 & 61.4 & 39.2 & 85.5 & 71.3 & 70.2 & 83.9 & 64.3 \\
\hline 15 & 50.0 & 50.5 & 38.1 & 83.9 & 52.1 & 51.7 & 53.0 & 54.4 \\
\hline Experimental group & 54.3 & 59.9 & 45.1 & 96.4 & 76.4 & 79.8 & 83.9 & 68.6 \\
\hline Bactericidal efficacy & $33 \%$ & $35 \%$ & $31 \%$ & $39 \%$ & $47 \%$ & $32 \%$ & $30 \%$ & $37 \%$ \\
\hline
\end{tabular}

Control group samples without Bio-Kil treatment were collected during the first 6 weeks of the experiment; experimental group samples were collected during the following 9 weeks from sites treated with Bio-Kil.

the treatment of the air-conditioning system with Bio-Kil, results from 3 sampling points (A, B and L) within the same waiting area (Clinics 35-40) showed that both A (80.6 $\pm 34.6 \mathrm{CFU} / \mathrm{h} /$ plate) and B (92.2 $\pm 65.8 \mathrm{CFU} / \mathrm{h} /$ plate $)$ had higher numbers of bacterial colonies than L $(65.9 \pm 11.4 \mathrm{CFU} / \mathrm{h} /$ plate). Although A was higher than $\mathrm{B}$, there was no statistical significance. The other 4 sampling points, belonging or close to Clinics 1-20, were: K (150.8 $\pm 111.6 \mathrm{CFU} / \mathrm{h} /$ plate $), \mathrm{D}(138.8 \pm 95.4 \mathrm{CFU} / \mathrm{h} /$ plate), F (124.5 $\pm 41.4 \mathrm{CFU} / \mathrm{h} /$ plate $)$ and M $(120 \pm 41.8 \mathrm{CFU} / \mathrm{h} /$ plate; Table I). Overall, the bacterial counts in the waiting areas of Clinics 35-40 (A, B and L) were markedly fewer than the bacterial counts of $\mathrm{K}, \mathrm{D}, \mathrm{F}$ and $\mathrm{M}$. In contrast to the first group, and quite surprisingly, the well-ventilated areas, including the hall $(\mathrm{K})$ and the waiting areas in Clinics 1-20 (M and D), had higher bacterial counts. Besides not replacing the regular filters for 6 weeks, the airborne bacterial counts showed a tendency to increase, indicating that the longer the filters were kept in place, the less effective their bacteria-filtering ability became. However, not only were the airborne bacterial counts affected by the length of time they were used, they also seemed to fluctuate in response to the volume of outpatient services (Fig. 2). Additionally, the results of our research supports the hypothesis that regular filters without treatment with Bio-Kil maintained average airborne bacterial counts at $108.8 \mathrm{CFU} / \mathrm{h} /$ plate, even though the actual indoor airborne bacterial counts varied with the age of the filters.

Following treatment of the air conditioners with Bio-Kil in the sampling points (A, B and $\mathrm{L}$ ) in the same waiting area (Clinics 35-40), B (59.9 $\pm 17.4 \mathrm{CFU} / \mathrm{h} /$ plate) had a higher number of colonies than A $(54.3 \pm 25 \mathrm{CFU} / \mathrm{h} /$ plate $)$, and $\mathrm{A}$ had a higher number of colonies than $\mathrm{L}(45.1 \pm 14.6 \mathrm{CFU} / \mathrm{h} /$ plate $)$. Following treatment with Bio-Kil in the other 4 sampling points, the results showed that D $(96.4 \pm 31.2 \mathrm{CFU} / \mathrm{h} /$ plate $)$ had a higher number of colonies than $\mathrm{M}(83.9 \pm 41.4 \mathrm{CFU} / \mathrm{h} /$ plate), K (79.8 $\pm 35.2 \mathrm{CFU} / \mathrm{h} /$ plate) and F $(76.4 \pm 25 \mathrm{CFU} / \mathrm{h} /$ plate). No statistically significant differences were found in the number of colonies in the $\mathrm{M}, \mathrm{K}$ and $\mathrm{F}$ sampling points. Overall, following the treatment of the air conditioners with Bio-Kil, the mean airborne bacterial counts were maintained at $\sim 68.6 \pm 19.6 \mathrm{CFU} / \mathrm{h} /$ plate. In addition, comparison of the differences prior to and following treatment with Bio-Kil indicated that the bactericidal efficacy remained at $30-47 \%$. It is noteworthy that, although the length of time using the regular filters impacted the airborne bacterial counts, 9 weeks after the treatment with Bio-Kil the airborne bacterial counts remained stable (Fig. 2). Although the fluctuation of outpatient services may affect airborne bacterial counts, the counts did not increase initially in response to the presence of more outpatient traffic, but increased gradually, following the 9-week installation of filters without replacement. This indicates that treatment with Bio-Kil is able to reduce the frequency of replacing filters.

Bactericidal study of Bio-Kil treatment of nursing staff uniforms. The sampling process was carried out according to the protocol and only one participant, whose lower hem 
Table II. Bacterial counts on the work clothing, including lower hems and cuffs of sleeves, with or without Bio-Kil treatment, compared by the Paired t-test.

\begin{tabular}{|c|c|c|c|c|}
\hline & \multicolumn{2}{|c|}{ Lower hems $\left(\mathrm{CFU} / 100 \mathrm{~cm}^{2}\right)$} & \multicolumn{2}{|c|}{ Cuffs of sleeves $\left(\mathrm{CFU} / 100 \mathrm{~cm}^{2}\right)$} \\
\hline & No Bio-Kil treatment & Bio-Kil treatment & No Bio-Kil treatment & Bio-Kil treatment \\
\hline Mean & 7,753 & 1,201 & 2,131 & 1,165 \\
\hline Variance & 446580027 & 6315842 & 3236693 & 1876016 \\
\hline No. of observers & 28 & 28 & 29 & 29 \\
\hline $\mathrm{P}(\mathrm{T} \leq \mathrm{t})$ one-tailed & \multicolumn{2}{|c|}{0.0401} & \multicolumn{2}{|c|}{0.0073} \\
\hline
\end{tabular}

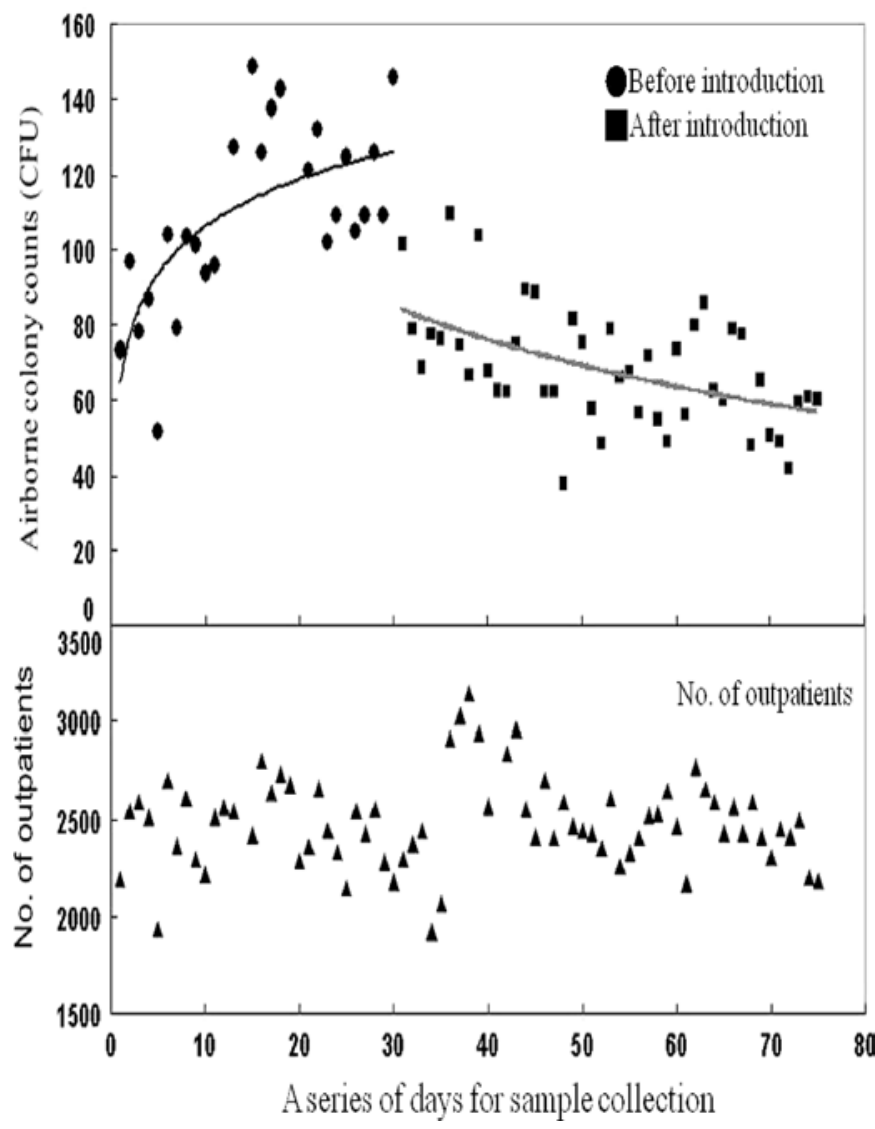

Figure 2. Following the use of Bio-Kil, total air bacteria counts/h from 7 collection sites were compared to the number of outpatients.

fabric was carelessly contaminated, was excluded. The results showed that the fabric patches on the lower hems of the uniforms treated with Bio-Kil had a mean bacterial count of 1,201 CFU/100 $\mathrm{cm}^{2}$, which was markedly lower (paired t-test; $\mathrm{p}=0.0401$ ) than that of the untreated fabric patches (mean 7,753 CFU/100 $\mathrm{cm}^{2}$; Table II). The treated fabric patches on the cuffs of sleeves had a mean bacterial count of 1,165 CFU/100 $\mathrm{cm}^{2}$, which was markedly lower (paired t-test; $\mathrm{p}=0.0073$ ) than that of the untreated fabric patches $\left(2,131 \mathrm{CFU} / 100 \mathrm{~cm}^{2}\right.$; Table II). No statistically significant differences (paired t-test; $\mathrm{p}=0.1681$ ) were found between the untreated fabric patches on the lower hem (mean $7,753 \mathrm{CFU} / 100 \mathrm{~cm}^{2}$ ) and the untreated fabric patches on the cuffs of the sleeves (mean 2,119 CFU/100 $\mathrm{cm}^{2}$; Table III).
The mean bacterial counts of the lower hems on the first, second and third days were $1,429 \pm 818791,11,736 \pm 6.1 \times 10^{8}$ and $9,277 \pm 6.2 \times 10^{8} \mathrm{CFU} / 100 \mathrm{~cm}^{2}$, respectively, and showed no statistically significant differences (one-way ANOVA; $\mathrm{p}=0.6584)$. Also, no statistically significant differences $(p=0.4297$ ) were found by one-way ANOVA between the bacterial counts of untreated cuffs on the sleeves of the nursing staff uniforms on the first, second and third days $(1,665 \pm 3529879$, $1,612 \pm 1458234$ and $2,531 \pm 3763746 \mathrm{CFU} / 100 \mathrm{~cm}^{2}$, respectively). These results indicate there as no difference in the bacterial counts performed on the first, second and third days.

Comparison and confirmation of different types of handcleaning methods. The mean bacterial counts on the palms of hands before washing was $196 \mathrm{CFU} /$ plate, including the bacterial counts of the left palm (199 CFU/plate; range 17-426) and the right palm (193 CFU/plate; range 11-437). No statistically significant differences were found between the bacterial counts of the left and right palms (paired t-test; $\mathrm{p}=0.47$ ).

The ten hand-cleaning methods used in this study were: hand-washing with i) tap water and natural drying, ii) tap water and paper towels, iii) liquid soap and paper towels, iv) $75 \%$ alcohol, v) Hibiscrub and paper towels, vi) Bio-Kil (1st generation), vii) Steridal Solution, viii) Fresh Protect Skin Sanitizer, ix) Bio-Kil (3rd generation) and $\mathrm{x}$ ) 'ozone natural dry'. These methods had a mean bacterial eradication rate of i) $-84 \%$, ii) $50 \%$, iii) $50 \%$, iv) $80 \%$, v) $76 \%$, vi) $60 \%$, vii) $84 \%$, viii) $73 \%$, ix) $80 \%$ and x) $36 \%$, respectively (Table IV).

Steridal Solution, $75 \%$ alcohol and Bio-Kil (3rd generation) had the highest bacterial eradication rates, $>80 \%$; Hibiscrub and Fresh Protect Skin Sanitizer ranked the second highest with rates, from 70 to $80 \%$. Bio-Kil (1st generation) tap water and liquid soap with paper towels had lower rates, from 50 to $60 \%$.

Notably, not only was tap water with natural drying unable to decrease the bacterial counts, but it actually increased them. Accordingly, except for hand-washing with tap water and natural drying, regardless of the types of hand-cleaning, the bacterial counts on the palms of hands decreased by as much as $50 \%(\mathrm{p}<0.05)$. No statistically significant differences were found between hand-washing with tap water or liquid soap, both of which carried a $50 \%$ eradication rate. For Bio-Kil, which physically eradicates bacteria, its 3rd generation had a better bacterial eradication rate $(80 \%)$ than its 1 st generation $(60 \%)$. If paper towels were not used after hand-washing, the bacterial counts increased by as much as $84 \%$. 
Table III. Cuffs of sleeves of work clothing were compared to lower hems using Paired t-test, in order to assess the area with the highest bacteria count.

\begin{tabular}{lcc}
\hline & Lower hems & Cuffs of sleeves \\
\hline Mean & 7,753 & 2,119 \\
Variance & 446580027 & 3351934 \\
No. of observers & 28 & 28 \\
t statistics value & 1.4160 & \\
$\mathrm{P}(\mathrm{T} \leq \mathrm{t})$ two-tailed & 0.1681 & \\
\hline
\end{tabular}

Table IV. Bacterial eradication rate for hand-cleaning methods.

\begin{tabular}{llcc}
\hline \multicolumn{1}{c}{$\begin{array}{c}\text { Hand-washing } \\
\text { methods }\end{array}$} & $\begin{array}{c}\text { Average } \\
(\%)\end{array}$ & $\begin{array}{c}\text { Standard } \\
\text { deviation } \\
(\%)\end{array}$ \\
\hline 1. & Tap water with natural drying & -84 & 94 \\
2. & Tap water with paper towels & 50 & 25 \\
3. & Liquid soap with paper towels & 50 & 25 \\
4. & 75\% alchol & 80 & 19 \\
5. & Hibiscrub with paper towels & 76 & 15 \\
6. & Steridal Solution & 84 & 15 \\
7. & Fresh protect skin sanitizer & 73 & 21 \\
8. & Ozone & 36 & 25 \\
9. & Bio-Kil (I) & 60 & 29 \\
10. & Bio-Kil (III) & 80 & 15 \\
\hline
\end{tabular}

\section{Discussion}

The A, B and L waiting areas in Clinics 35-40 were closed regions and had relatively lower airborne bacterial counts. The well-ventilated hall $(\mathrm{K})$ and the waiting areas of Clinics 1-20 ( $\mathrm{M}$ and D) had relatively higher airborne bacterial counts, which could be due to the fact that contact with the outside environment tended to increase airborne bacterial counts. Nevertheless, the environmental airborne bacterial counts may change with the outside air quality daily, especially considering the impact of airflow, temperature and humidity, which all affect indoor air quality. Long-term monitoring is required to confirm the actual conditions.

The filters treated with Bio-Kil demonstrated a reduced need of the frequency of replacement, but no definite evidence indicated specifically how often filters required changing. Theoretically, a hospital indoor airborne bacterial count of more than $120 \mathrm{CFU} / \mathrm{h} /$ plate is the reference value for filter replacement. After 3 weeks, filters without treatment with Bio-Kil had an airborne bacterial count of more than $120 \mathrm{CFU} / \mathrm{h} /$ plate in some sampling sites. In order to maintain a high level of air quality, the filters may need to be changed more frequently. However, the filters treated with Bio-Kil had fewer than $120 \mathrm{CFU} / \mathrm{h} /$ plate in all sampling sites following 9 weeks of use. When the treated filters were initially installed, the airborne bacterial counts were slightly higher, but did not exceed $120 \mathrm{CFU} / \mathrm{h} /$ plate. Later, the airborne bacterial counts gradually decreased and this may be explained by the fact that when Bio-Kil was first used, it was during the weekly peak of outpatient services. When Bio-Kil was used, variations in the airborne bacterial counts were smaller. During the 9-week experimental process, the highest value never exceeded $120 \mathrm{CFU} / \mathrm{h} /$ plate (Table I).

Additionally, since the long-term use of filters results in the accumulation of a great amount of bacteria, many bacteria may become detached. This could not only jeopardize the health of the staff, but could also cause bacteria to enter the airconditioning circulation as pollution. However, the microbes attached to the filters treated with Bio-Kil were eradicated, thus reducing the risk of infection for the staff. Moreover, Bio-Kil kills the bacteria physically. Although the mechanism is not commonly viewed as a chemical sterilization method, which has less influence on human health, Bio-Kil will not cause resistance nor have attrition over time because of its physical characteristics.

In general, treatment with Bio-Kil reduces airborne bacterial counts, kills the bacteria attached to air conditioner filters, extends the life span of air conditioner filters and reduces the frequency of filter replacement. These outcomes not only protect the Department of Maintenance from possible infection during the replacement of the filters, but also prevent the instant spread of bacteria during the reinstallation of filters. Regarding the frequency of the filter reinstallation and the species of bacteria and viruses that Bio-Kil is unable to eradicate, these will be the primary issues of future studies. The evaluation of treatment with Bio-Kil in other disease prevention situations, such as the dynamic bactericide in the air-conditioning pipelines and the bactericidal surfaces of waiting-room seats and walls, will also be part of the focus of future investigations. The aim of the current study was to provide a reference for disease prevention efforts in hospitals, which involves reducing nosocomial infections due to poor air quality.

Regarding the tests on the uniforms of the nursing staff, the mean bacterial counts differed between the untreated lower hems on the first and second days (1,429 vs. 11,736 $\mathrm{CFU} / 100 \mathrm{~cm}^{2}$ ). However, one-way ANOVA did not show statistically significant differences, and the F test was performed to determine whether the population variance was equal or not. $F$ test showed that the population variances were not the same $(\mathrm{p}<0.001)$. Accordingly, considering the assumption of unequal variances, no statistical significance was found for the mean bacterial count of the hems on the first and second days, using Student's t-test to determine the population mean difference $(p=0.4034)$. This indicates that there was no difference in the bacterial counts on the lower hems on the first and second day, and we should not rely on observing the mean bacterial count. The regression of the number of patients cared for during a given period and the number of isolated bacteria counts showed a low $\mathrm{R}$ value $(0.1591)$, which indicates a weak association of the regression equation of the number of patients cared for and the number of isolated bacteria counts. The $p$-value of the slope in the equation, $y=1278 x-6855$, was only 0.4186 , and the p-value of the intercept was only 0.7098 , without fitting inside the value of 0.001 . Therefore, the regression equation did not yield constructive results. As a result, the inclusion of the number of patients cared for does not provide 
precise estimation. The regression of the number of patients cared for during a given period and the number of isolated bacteria counts from the cuffs showed a very low $\mathrm{R}$ value (0.0450), suggesting a weak association between the number of patients cared for and the number of isolated bacteria counts. Additionally, the p-value of the slope in the equation, $y=31.2 x+1777$, was only 0.8166 , and the $p$-value of the intercept was only 0.2627 , without fitting inside the value of 0.001 . Therefore, the regression equation was not significant. As a result, the inclusion of the number of patients cared for does not provide precise estimation of bacterial counts taken from the cuffs. The fabric patches treated with Bio-Kil on the lower hems and the cuffs had a markedly lower bacterial count than that of the untreated fabric patches. We did not conclude that the lower hems and the cuffs were dirtier due to more days of wear. The number of patients in the nurses' care was weakly associated with the bacterial counts on the lower hems and cuffs.

From the perspective of disease prevention, dry sanitizers provide better accessibility. The advantages of dry sanitizers are freedom from paper towels and reduced paper waste. The main bactericidal effects of dry sanitizers may be positively associated with their alcohol concentration. In theory, the higher the alcohol concentration, the more effective the sterilization would be. However, higher alcohol concentration causes more damage to the skin and is not necessarily the best protection, as, for example, some people are allergic to alcohol.

No statistical significance was found in this study between the bacterial counts on the left and right palms of hands. This may not be entirely accurate and is a possible limitation of the study. Error is less likely to occur only if the same palm is checked before and after hand-washing. However, based on the experimental design, it was not possible to use the same palm, mainly because hand-washing may not be responsible for the bacterial reduction. Instead, it could be considered that the reduction was due to the attachment of bacteria on the plate before washing. Bio-Kil improved the efficacy of airconditioning and the cleanliness of nurses' uniforms and had the highest bacterial eradication rates (more than $80 \%$ ).

The greatest challenge of this study was that the majority of the participants were medical staff. In certain experimental processes, the necessary avoidance of gloves and dry or wet hand-washing interfered with work procedures to a certain degree. Besides this, in the sampling process it was not always possible to avoid interrupting the medical staff and the performance of their procedures. Occasional difficulties also occurred in the execution of the research, which took more than a year to complete.

\section{Acknowledgements}

The authors would like to thank the Cargico Group Corp. who supplied the bactericidal materials used in the experiment.

\section{References}

1. Martone WJ, Jarvis WR, Culver DH and Haley RW: Incidence and nature of endemic and epidemic nosocomial infections. In: Hospital Infections. Bennett JV and Brachman PS (eds.). Little, Brown and Company, Boston, pp577-596, 1992.

2. Delaney LR and Gunderman RB: Hand hygiene. Radiology 246: 15-19, 2008.

3. Garner JS and Favero MS: CDC guideline for handwashing and hospital environmental control. Infect Control 7: 231-243, 1986.

4. Larson E: Guideline for use of topical antimicrobial agents. Am J Infect Control 16: 253-266, 1988.

5. Larson EL, APIC Guidelines Committee: APIC guideline for handwashing and hand antisepsis in health care settings. Am J Infect Control 23: 251-269, 1995.

6. Hospital Infection Control Practices Advisory Committee (HICPAC): Recommendations for preventing the spread of vancomycin resistance. Infect Control Hosp Epidemiol 16: 105-113, 1995.

7. Garner JS, Hospital Infection Control Practices Advisory Committee: Guideline for isolation precautions in hospitals. Infect Control Hosp Epidemiol 17: 53-80, 1996.

8. Pittet D, Mourouga P, Perneger TV; Members of the Infection Control Program: Compliance with handwashing in a teaching hospital. Ann Intern Med 130: 126-130, 1999.

9. Boyce JM: It is time for action: improving hand hygiene in hospitals. Ann Intern Med 130: 153-155, 1999.

10. Tibballs J: Teaching hospital medical staff to hand wash. Med J Aust 164: 395-398, 1996.

11. Pittet D: Compliance with hand disinfection and its impact on hospital-acquired infections. J Hosp Infect 48: 40-46, 2001.

12. Bischoff WE, Reynolds TM, Sessler CN, et al: Handwashing compliance by health care workers: the impact of introducing an accessible, alcohol-based hand antiseptic. Arch Intern Med 160: 1017-1021, 2000.

13. Boyce JM and Pittet D: MMWR: Recommendations of the Healthcare Infection Control Practices Advisory Committee and the HICPAC/SHEA/APIC/IDSA Hand Hygiene Task Force: http://www.cdc.gov/mmwr/PDF/rr/rr5116.pdf, 2002. 